\title{
The Forty-second Annual ISNA Convention
}

The theme of this year's event, "Muslims in North America: Accomplishments, Challenges, and the Road Ahead," was a public proclamation that North American Muslims are focusing on the future. One highlight was the presence of Undersecretary of State for Public Diplomacy Karen Hughes, who met with heads of Muslim American organizations on the grounds that she needed their advice to help her reach out to the wider Muslim world. Overall, the convention focused on advancing values of the family, community, compassion, and justice; the workshops addressed community building, organizing politically, promoting civil rights, opposing Islamophobia, sharing Islam, and promoting interfaith understanding.

The conference was inaugurated by the leaders of ISNA's constituent organizations and leaders of other faiths. Bob Edgar (secretary general, National Council of Churches), set the tone: "If you want to walk fast, walk alone. If you want to walk far, walk together!” Muhammad Nur Abdullah (president, ISNA) spoke of such ISNA accomplishments as the imam and chaplain training services and empowering Muslim youths. The inaugural session was addressed by Khurshid A. Qureshi (president, AMSE) Rafik Beekun (president, AMSS), Rehana Kausar (president, IMANA), Mohammad Sheibani (president, MSA), and co-chairs Omar Siddiqi and Kulsoom Salman (both of MSA-National). Ingrid Mattson (vice president, ISNA; director, Islamic chaplaincy; and professor, Islamic studies and Christian-Muslim relations, Hartford Seminary), Abdul-Malik Mujahid (president, Council of Islamic Organizations of Greater Chicago), Bob Edgar (secretary general, National Council of Churches), and Rick Ufford-Chase (chair of the moderator of the 216th General Assembly of the Presbyterian Church [USA]).

The ISNA Dr. Mahboob Khan Community Service Award was presented to Ilyas Ba-Yunus, a founding member of MSA who helped establish ISNA and served as its first president. A respected sociologist, he is the author of several studies related to Muslim life in America. Former Malaysian deputy prime minister Anwar Ibrahim, the keynote speaker at the Community Service Recognition luncheon, expressed his gratitude for ISNA's role in securing his release after the charges brought against him by former prime minister Mahathir Muhammad failed the court test. In keeping with a now 3-year-old tradition, Anwar received an award recognizing his contribution to democracy, civil society, and social justice. 
In the "Challenges Ahead" panel, ISNA introduced its newly established Anti-Terrorism and Anti-Extremism Committee (ATAEC), which will work on short- and long-term plans against extremism and terrorism and release a new publication explaining the Islamic position. Its head explained that irrespective of the Muslims' legitimate grievances against the West, terrorism is the epitome of injustice because it targets the innocent. Jihad cannot be equated with terrorism, because it does not mean "holy war." According to Jamal Badawi (ISNA Majlis al-Shura and Fiqh Council of North America), jihad comes from $j$ - $h$ - $d$ (exertion). The Qur'an mentions many types of jihad, such as telling the truth and keeping one's money pure. Combative jihad is a last resort, which the Qur'an calls qital (fighting). Corey P. Saylor (government affairs director, Council on American-Islamic Relations [CAIR]), explained how to pressure politicians who smear Islam, the benefits of corporate boycotts, and what constitutes legal grounds for defamation suits.

Sami Beg presented his vision for a social justice organization known as Doctors for Humanity (DFH), which seeks to combat and dismantle the "cancer" of consumerism through mentoring, investing in education, building social institutions to establish a stronger academic base, using the media to convey a positive message, and integrating peace and humanity into our lives. Maha ElGenaidi (founder and president, Islamic Networks Group) recommended that Muslims proactively counter negative perceptions and project a positive image via their exemplary behavior. Scott Alexander (director, Catholic-Muslim Studies Program, Catholic Theological Union) shared Biblical and Qur'anic (4:36) verses on clarifying who are "strangers" and "neighbors." Salam al-Marayati (executive director, Muslim Public Affairs Council) warned that many Muslim youths are either uncomfortable with their identity or are becoming self-righteous. This leads them into a "psychological ghetto," a "victim" worldview, and possibly to cultural schizophrenia.

ISNA expressed its interest in interfaith dialogue by holding more than five interfaith issues, apart from the Unity Banquet. Sayyid M. Syeed (secretary general, ISNA) explained that the banquet is "an opportunity for leaders of diverse religions, including the Catholic, Protestant, Jewish, and Muslim communities, to come together, renew their bonds, and forge a path of partnership for the future.” Fr. Francis Tiso (director, Bishops' Committee on Ecumenical and Interreligious Affairs) expressed his deep admiration for such commitment. Rev. W. Douglas Mills (associate general secretary for dialogue and interfaith relations, General Commission on Christian Unity and Interreligious Concerns, The United Methodist Church) said: "I was 
impressed by the great variety of seminars that you made available and by the quality within the seminars that I attended. It is probably no surprise that I was particularly interested in the seminar "Building Bridges of Faith: Legacy of Abraham and Interfaith Cooperation' moderated by Faroque Khan.” Hina Azam (professor, Islamic Studies, University of Texas at Austin), who specializes in Islamic law, discussed how the North American Muslim community manages its own diversity without falling into schism and sectarianism.

Civil rights attorney Maaria Mozzafar stated that 60-70 percent of refugees in America are Muslims, but there is no strong organization to help them. Abdul Basit (Northwestern University) stressed the need to "develop comprehensive strategies for the resettlement of Muslim refugees" and to help them retain their identity. Farid Esack (chair, Brueggeman Center for Dialogue, Xavier University), a veteran social activist, stated that "it is not enough to be Muslim,” for Muslims must bring about peace and justice wherever they go. A. Rashied Omar (coordinator, Joan B. Kroc Institute's Program in Religion, Conflict, and Peace Building, University of Notre Dame) defined social justice as "a concept that transcends self interest and sectarianism, even if it is against yourselves.” Rev. Calvin O. Butts (president, SUNY) stated: "Justice is elusive. We pursue it knowing that compassion is the ground we can stand on. If we all have the same notions of ways to carry out justice, then our communities can be stronger together.”

ISNA Convention Reporters Committee Chicago, IL 